NBER WORKING PAPER SERIES

\title{
WHAT DRIVES LAND-USE CHANGE IN THE UNITED STATES? A NATIONAL ANALYSIS OF LANDOWNER DECISIONS
}

\author{
Ruben N. Lubowski \\ Andrew J. Plantinga \\ Robert N. Stavins \\ Working Paper 13572 \\ http://www.nber.org/papers/w13572 \\ NATIONAL BUREAU OF ECONOMIC RESEARCH \\ 1050 Massachusetts Avenue \\ Cambridge, MA 02138 \\ November 2007
}

This paper is based, in part, on Lubowski's Ph.D. dissertation at Harvard University. The authors thank Michael Roberts, Patrick Sullivan, and two anonymous reviewers for very helpful comments and acknowledge financial support from the U.S. Department of Energy. The opinions expressed are those of the authors and may not be attributed to the Economic Research Service, the U.S. Department of Agriculture, the U.S. Department of Energy, the National Bureau of Economic Research, or any other institution.

(C) 2007 by Ruben N. Lubowski, Andrew J. Plantinga, and Robert N. Stavins. All rights reserved. Short sections of text, not to exceed two paragraphs, may be quoted without explicit permission provided that full credit, including $\odot$ notice, is given to the source. 
What Drives Land-Use Change in the United States? A National Analysis of Landowner Decisions

Ruben N. Lubowski, Andrew J. Plantinga, and Robert N. Stavins

NBER Working Paper No. 13572

November 2007

JEL No. Q1,Q15,Q23,Q24

\begin{abstract}
Land-use changes involve important economic and environmental effects with implications for international trade, global climate change, wildlife, and other policy issues. We use an econometric model to identify factors driving land-use change in the United States between 1982 and 1997. We quantify the effects of net returns to alternative land uses on private landowners' decisions to allocate land among six major uses, drawing on detailed micro-data on land use and land quality that are comprehensive of the contiguous U.S. This analysis provides the first evidence of the relative historical importance of markets and Federal farm policies affecting land-use changes nationally.
\end{abstract}

Ruben N. Lubowski

USDA Economic Research Service

1800 M Street, N.W., Room S4177

Washington, D.C. 20036

RLUBOWSKI@ers.usda.gov

Andrew J. Plantinga

Agricultural \& Resource Economics

University of Oregon

Rm \#212B Ballard Extension Hall

Corvallis, OR 97331-4501

Plantinga@oregonstate.edu
Robert N. Stavins

JFK School of Government

Harvard University

79 JFK Street

Cambridge, MA 02138

and NBER

robert_stavins@harvard.edu 


\section{INTRODUCTION}

Over the past quarter century, the United States has experienced dramatic land-use changes - including declines in cropland, increases in forests, and accelerated expansion of urban areas — that depart from trends over the previous decades. ${ }^{1}$ Broad-scale changes in land use produce important effects with implications for international trade, global climate change, wildlife habitat and a host of other policy issues. For example, land use has figured prominently in international negotiations on climate change. Under the Kyoto Protocol, countries can claim credit for offsetting carbon dioxide $\left(\mathrm{CO}_{2}\right)$ emissions through changes in land use and land management. Also, in communities across the United States, "urban sprawl” has been a concern voiced by many citizens (Pew 2000). And the current Doha Round of the World Trade Organization (WTO) has stalled over the issue of reducing agricultural support programs in the United States and Europe (e.g., WTO, 2006). Developing nations oppose these programs on the grounds that they increase production and lower global crop prices (e.g., Oxfam 2003).

What has caused the changes in land use that have occurred in the United States over the past twenty-five years? What has been the role of major Federal farm policies? We investigate the influences of different economic and policy factors on national land use from 1982 to 1997 by estimating an econometric model of the revealed preferences of landowners drawing on detailed micro-data on land use and land quality. Our model measures the effects of estimated net returns to alternative land uses on decisions by private landowners to allocate their land among six major uses: crops, pasture, forest, urban, range, and a Federally-financed use, the

\footnotetext{
${ }^{1}$ Between 1982 and 2002, total cropland in the 50 United States, including land in conservation programs, declined by 27 million acres (6\%) after rising 25 million acres over 1964-82 (Lubowski et al. 2006b). Forest area grew by 11 million acres (2\%) over 1987-2002 after falling 24 million acres over 1963-1987 (Smith et al. 2004). The average urbanization rate rose from 1.0 to 1.4 million acres annually from 1960-90 to 1990-97 (Vesterby and Krupa 1995).
} 
Conservation Reserve Program (CRP). ${ }^{2}$ Because individual landowners are likely to take prices and production technologies as given, we focus on net returns as the drivers of land-use change, abstracting from the various underlying factors affecting the net returns for land. These fundamental drivers include population growth, consumer tastes, international trade, and other factors affecting the demand for land in different uses. Underlying drivers also include weather, technology, local rules, and other factors determining production possibilities from different land-use alternatives.

Our national-level model allows us to estimate the impacts on land-use decisions of Federal policies, such as CRP, and other factors affecting the land base nationwide. Previous econometric land-use studies have focused on relatively small geographic areas, such as single regions or States. The few studies using national-level data have examined changes in a single land-use category, without modeling competition among land-use alternatives. ${ }^{3}$ Modeling this competition is critical for measuring the impact of factors affecting land-use choices when multiple land-use options are economically viable. We estimate a national model that accounts for transitions among a comprehensive set of major private land-use categories. ${ }^{4}$ Detailed data on the same points of land over time allows us to model transitions among different land uses rather than just net changes in particular category — and to account for variation in land quality that affects the profitability and corresponding choice of alternative uses.

\footnotetext{
${ }^{2}$ The CRP, established by the Food Security Act of 1985, is the largest Federal program targeting land use. The program offers rental payments to landowners who voluntarily retire environmentally sensitive cropland under 10to 15 -year contracts. CRP presently pays about $\$ 1.8$ billion per year to retire 36.1 million acres (about the size of Iowa) (FSA 2006).

${ }^{3}$ Previous national-level econometric studies examined urban area (Alig and Healy 1987), conservation programs (Parks and Kramer 1995; Plantinga, Alig and Cheng 2001), and timberland (Plantinga and Buongiorno 1990).

${ }^{4}$ While land-use categories can always be subdivided more specifically, our categories are more detailed than the “major" private uses reported in the USDA's Major Land Uses data series, the only accounting of land use for the entire nation (e.g., Lubowski et al. 2006b). In contrast to this series, we distinguish CRP from cropland; differentiate pasture and range; and exclude miscellaneous uses that are not identified.
} 
Most econometric analyses of land use examine the relationship between observed landuse patterns and measures or proxies for land rents (see Bockstael and Irwin 2000 for a review), but there has been little analysis of the relative importance of various factors in driving land-use changes. One exception was provided by Stavins and Jaffe (1990), who used an econometric model based on county data to examine the relative importance of Federal flood control projects and other factors in driving the depletion of forested wetlands in the Mississippi Delta from 1935 to 1984 . Our study extends their analysis by examining changes among a comprehensive set of major private land-use categories on a national scale. We use econometric estimates to simulate national changes in landowners' willingness to supply land in various uses from 1982 to 1997 under a series of scenarios that isolate the impact of particular market and policy factors.

Changes in national land use will influence the production of crops, timber, and other land-based commodities, affecting the prices for these products and, in turn, the incentives to allocate land among alternate uses. While we do not explicitly model these feedbacks, our simulations suggest the direction of impacts and relative importance of different factors affecting national land use. We also compare results from simulations using smaller changes in market and policy factors for which price feedbacks are likely to be minor.

To model both the supply and demand for land, other researchers have developed optimization models of the agriculture and forestry sectors. For example, Alig, Adams, and McCarl (1998) examined different future scenarios for CRP, farm program payments, and afforestation policies using a two-sector, multi-period simulation model, in which the forest and agricultural sectors are linked, and the welfare of producers and consumers in the two sectors is maximized. ${ }^{5}$ While such models enable simulations of market or policy changes accounting for

\footnotetext{
${ }^{5}$ Other applications of this Forest and Agricultural Sector Optimization Model (FASOM) include Alig et al (1997), Adams et al. (1999), McCarl and Schneider (2001), and EPA (2005).
} 
both changes in land use and corresponding prices, optimization models are limited in their ability to measure the impacts of different factors on land use historically and, to our knowledge, have not been used for this purpose. Optimization models are governed by assumed decision rules and elasticities and cannot incorporate all factors that affect land use in reality. These factors include option values in the face of uncertainty and irreversible investments, liquidity constraints, and unobserved market or non-monetary costs or benefits (Stavins 1999). Existing models are also limited to changes among agricultural and forest uses, rather than the broad set of land uses considered in our study. Our revealed preference approach aims to address some of these limitations and, in doing so, could provide estimates for calibrating or cross-validating optimization analyses.

We find that private land-use decisions have depended critically on land quality and have been steered by anticipated economic returns to alternative uses, which in some cases have been affected significantly by public policies, sometimes intentionally and sometimes unintentionally. Our results have implications for a number of policy issues related to land use. For example, with regard to potential market impacts from Federal farm programs, we find that positive effects on crop acreage of all direct Federal payments to farmers were more than offset by cropland retirement under the CRP. ${ }^{6}$ Indeed, we estimate that, in total, these Federal farm programs resulted in a modest decline in U.S. cropland area.

\section{ECONOMETRIC LAND-USE MODEL}

Consider a risk-neutral and price-taking landowner facing the choice of allocating a

\footnotetext{
${ }^{6}$ Federal funds paid directly to farmers include commodity programs, disaster assistance, land retirement and other conservation programs, and miscellaneous payments. Funds paid under commodity and disaster programs averaged $\$ 6.3$ billion annually from 1982 to 1997 (ERS 2003).
} 
parcel of land of uniform quality among a set of alternative uses. ${ }^{7}$ We posit that landowners choose uses to maximize the present discounted value of the stream of expected net benefits from the land, and base their expectations of future land-use profits on current and historic values of relevant variables. Landowners would expect current values to persist over time if land-use net returns follow a random walk. Limited empirical evidence suggests that this is approximately true (Schatzki 2003). For simplicity, our analysis also abstracts from the effects of uncertainty in the presence of fixed, irreversible costs (Dixit and Pindyck 1994). We thus model land-use choices as if landowners ignore the value of the option to delay irreversible costs and obtain additional information. ${ }^{8}$

Given these simplifying assumptions, the decision rule that emerges from the related dynamic optimization problem is to choose the use with the highest expected one-period return at time $t$ minus the current one-period expected opportunity cost of undertaking conversion (Lubowski 2002). With $K$ potential land uses $(j, k=1, \ldots, K)$, the owner of a unit of land in use $j$ will choose the use $k$ at time $t$ that satisfies:

$$
\underset{k}{\arg \max }\left(R_{k t}-r C_{j k t}\right) \geq R_{j t},
$$

where $R_{j t}$ and $R_{k t}$ represent the instantaneous expected net benefits at time $t$ from a unit of land in use $j$ and $k$, respectively; $C_{j k t}$ is the expected marginal cost of converting one unit of land from use $j$ to use $k$ at time $t\left(C_{j j t}=0\right)$; and $r$ is the discount rate. If the use $k$ satisfying equation 1

\footnotetext{
${ }^{7}$ If net returns and the costs of converting land between different uses are approximately linear in land quantity, the size of parcels will not affect the relative profitability of land-use options, in which case land-use decisions for a heterogeneous parcel can be treated as the sum of land-use choices on constituent uniform-quality parcels. While studies show that parcel size affects the value of land for urban development due to costs of subdividing and assembling parcels (e.g. Thornes and Miller 1998), we do not model these effects for lack of data and because urban development is a small share of the land-use changes considered.

${ }^{8}$ Given the broad scope of our analysis, it would be impossible to model explicitly the landowners' stochastic dynamic optimization problem (Rust 1987). However, our econometric approach incorporates option values
} 
equals $j$, then the land unit will remain in its current use at time $t$; otherwise, the landowner will reallocate the land to the use $k \neq j$ that maximizes expected net returns after conversion costs.

The landowner's profit function may be thought of as including both observed and unobserved components. Specific restrictions on the structure of the unobserved components yield alternative specifications of probabilistic models. An ordinary logit model is one obvious possibility, but the assumption of independent disturbances in the simple logit model implies that the ratio of the probabilities of any two choices is independent of the other alternatives.

We allow for differences in substitutability among alternatives using a nested logit specification, which imposes this property of "independence of irrelevant alternatives" within but not across specified subgroups ("nests") of choices. Dividing the choice set into mutually exclusive subgroups $K_{s}(s=1, \ldots, S)$, we specify $U_{i j k t}$, the landowner's utility from converting land parcel $i$ from use $j$ to use $k$ at time $t$, as the sum of a component, $V_{i j k t}$, that is unique to the alternative $k$ and another component, $V_{i j s t}$, that is common to all the alternatives in $K_{s}$. Each of these components, in turn, includes an observed component plus an unobserved component characterized as a random error.

Under assumptions analogous to the standard logit model, the probability of choosing alternative $k$ that is grouped in $K_{s}$ can be expressed as the product of two terms: the probability, $P_{i j s t}$, of choosing any of the alternatives within $K_{s}$; and the conditional probability, $P_{i j k t s}$, of choosing $k$ given the choice of $K_{s}{ }^{9} \quad$ For land parcel $i$ starting in use $j$, the probability of choosing land use $k \in K_{s}$ between time $t$ and $t+1$ is thus:

indirectly. If fixed costs and other irreversible choices introduce rigidities in land use, these will be reflected in the estimated coefficients. 


$$
P_{i j k t}=P_{i j s t} \cdot P_{i j k t \mid s}=\frac{\exp \left(V_{i j s t}+\tau_{s t} I_{i j s t}\right)}{\sum_{s=1}^{S} \exp \left(V_{i j s t}+\tau_{s t} I_{i j s t}\right)} \cdot \frac{\exp \left(V_{i j k t}\right)}{\sum_{l=1}^{J_{s}} \exp \left(V_{i j l t}\right)},
$$

where $\tau_{s t}$ are parameters, and $I_{s}=\ln \sum_{l=1}^{J_{s}} \exp \left(V_{i j l t}\right)$. This “inclusive value” for nest $K_{s}$ equals the expected utility for the choice of alternatives within a nest. The expression in equation 2 embodies the first-order Markov property since the probability of the parcel changing use depends only on exogenous covariates at time $t$.

Our chosen nesting structure is based on the premise that land uses with more similar land quality requirements are closer substitutes. ${ }^{10}$ We expect land quality to affect land-use net returns principally in terms of agricultural yields, and we proxy land quality using the Land Capability Class (LCC), a summary measure of the suitability of land and associated climate for producing crops (USDA 1973). ${ }^{11}$ Land in crops has the highest average quality as measured by the LCC, while pasture and CRP uses tend to be adopted on higher quality lands relative to forest and range uses. $^{12}$ In the case of CRP, program rules restrict which lands are eligible to participate; notably, eligibility is limited to lands that were planted to an agricultural commodity for four of the previous six crop years. We incorporate these differences in land quality requirements by specifying our nested logit model with three nests: $K_{1}$ (crops, CRP, and

\footnotetext{
${ }^{9}$ Assumptions of the nested logit model imply that the two disturbances are independent and that their sum has the Gumbel distribution (Ben-Akiva and Lerman 2000).

${ }^{10}$ Land quality is only one potential determinant of substitutability among land uses. To the extent that farmers operate joint crop and livestock operations, farmers may have skills for pasture and range uses - rather than forestry, for example - so crops, pasture, and range uses may be closer substitutes for each other than for other uses. On the other hand, forest and pasture are similar in terms of lower labor requirements.

${ }^{11}$ The LCC measure was designed to target conservation programs, rather than to measure soil productivity, and allows local flexibility in rankings, producing some inconsistencies across regions (Douglas 1992). Despite these limitations, we use LCC because estimated crop yields, the Soil Rating for Plant Growth (SRPG) (Soil Survey Staff 2000), and other explicit productivity measures are not currently available for all soil types and land uses.

${ }^{12}$ As a rough indicator, assigning values 1 through 4 to LCCs I-II, III-IV, V-VI, and VII-VIII, respectively, the NRI indicates that the average qualities in the contiguous U.S. over 1982-97 were 1.5 for cropland, 1.9 for CRP, 2.0 for pasture, 2.2 for urban land, 2.7 for forests, and 3.0 for range, with lower values indicating higher quality.
} 
pasture); $K_{2}$ (forest and range); and $K_{3}$ (urban). We model urban land use as a unique nest, due to its greater degree of irreversibility, and because land quality, as measured by the LCC, is likely to be a much less important determinant of urban development returns.

Landowners presumably compare net returns to alternative uses on particular parcels. Although we have land-use data at the parcel level, we lack parcel-level observations of net returns. Instead, we observe county-level average returns and, to allow for parcel-level variation, we interact the average-return variables for each land use with parcel-level indicators of land quality. The county-average return for a particular use reflects the average return on those parcels of land in the county currently in that use. The estimated land quality adjustment factors scale this average net return to approximate the net returns to each use on every parcel of land, regardless of its current use. The magnitude of the land quality adjustment could be different for different land uses depending on the sensitivity of the different net returns to land quality as well as on the land quality distribution for the land in each use. In reality, in large parts of the country, forests, range, or other land uses in our choice set may not be a feasible alternative given climatic conditions or other biophysical, economic, or legal constraints. Given the national focus of our study, our model captures the average effects of LCC on land-use conversions but does not identify in what specific locations these effects might be more or less important.

We thus specify the component of utility that is unique to each alternative as:

$$
V_{i j k t}=\alpha_{j k t}^{0}+\alpha_{j k t}^{q} L C C_{i t}^{q}+\beta_{j k t}^{0} R_{k c}+\beta_{j k t}^{q} L C C_{i t}^{q} R_{k c}+\varepsilon_{i j k t},
$$

where $\alpha_{j k t}^{0}$ is an alternative-specific intercept, $\alpha_{j k t}^{q}, \beta_{j k t}^{0}$, and $\beta_{j k t}^{q}$ are parameters, ${ }^{7} R_{k c}$ is the level of net returns to use $k$ in county $c,{ }^{8} L C C_{i t}^{q}$ is a dummy variable indicating whether parcel $i$ is of 
quality $q$ at time $t$, and $\varepsilon_{i j k t}$ is the error term. ${ }^{13}$ We lack data on the costs of changing land use, but we expect these costs to be closely related to land cover as well as slope and other factors affecting LCC. Accordingly, we model conversion costs with the terms $\alpha_{j k t}^{0}+\alpha_{j k t}^{q} L C C_{i t}^{q}$ in equation 3, which provide an intercept term varying with initial use and our land quality proxy. ${ }^{14}$ CRP participation depends on a different set of decisions than other land-use choices, because enrollment depends on both the landowner's bid, which includes a proposed rental rate, and the government's choice of whether to accept the bid, which depends on the environmental characteristics of a parcel as well as the cost. Because the program targets cropland, CRP rental rates are highly correlated with the profitability of cropping in a given locality. We account for the effect of crop net returns on the incentive to remain in cropland. Incentives to enroll in CRP are specified as a function of LCC, which was a consistent element of the program's eligibility criteria during our period of analysis. ${ }^{15}$ Also, because CRP rental rates are subject to caps, only lands earning returns below this cap are likely to be enrolled in the program. For these reasons, greater enrollment would be expected on lower quality croplands, as proxied by LCC. Equation 3 thus becomes $V_{i j k t}=\alpha_{j k t}^{0}+\alpha_{j k t}^{q} L C C_{i t}^{q}+\varepsilon_{i j k t}$ for $k=C R P$.

\footnotetext{
${ }^{13}$ The eight LCCs are merged into four groups: I-II, III-IV, V-VI, and VII-VIII.

${ }^{14}$ Costs of converting land to crops, such as clearing and drainage, have been estimated at State and regional levels (e.g., Heimlich et al. 1998). We proxy such costs with LCC as they are likely to be very site specific and because explicit cost estimates are not available for most of the land-use changes in our model. We expect conversion costs to increase with slope, erodibility, excess water, and stoniness, which are key factors proxied by higher LCC. An anonymous reviewer noted that conversion costs could inversely vary with LCC if more productive lands have more vegetation requiring clearing. The intercept term varying by initial use will partially proxy for vegetative cover.

${ }^{15}$ Until sign-up 13 in 1995, all lands with LCC ratings VI-VIII were eligible for CRP, while lands in LCC II-V were only eligible subject to erosion criteria and other requirements which changed over time. We did not include erosion factors in the NRI data as determinants of CRP participation because eligibility as measured by these variables was not correlated with CRP enrollments, possibly due to insufficient sampling of CRP parcels.
} 
For the component of utility that is constant across the alternatives within each nest, we include constant terms for the nest and interactions with the land quality indicator variables. For land parcel $i$ in use $j$, the component of utility that is constant within each nest is thus:

$$
V_{i j s t}=\gamma_{j s t}^{0}+\gamma_{j s t}^{q} L C C_{i t}^{q}+\tau_{s t} I_{i j s t},
$$

where $\gamma_{j s t}^{0}$ is a constant specific to nest $s$ and $\gamma_{j s t}^{q}$ is a coefficient on the land quality indicators. Substituting equations 3 and 4 into 2 yields a complete nested logit model for estimation.

We estimate the model using repeated observations of land use on individual parcels from the National Resources Inventory (NRI) of the U.S. Department of Agriculture's Natural Resources Conservation Service (NRCS). The NRI is a panel survey of land use and land characteristics on non-Federal lands conducted at five-year intervals from 1982 to 1997 over the entire United States, excluding Alaska. ${ }^{16}$ Data include about 844,000 sample “points,” each representing a land area given by a sampling weight (Nusser and Goebel 1997). We observe land use at each point in four survey years, providing information on land-use changes over three transition periods: 1982-87, 1987-92, and 1992-97. We focus on six land uses: crops, pasture, forest, urban, range, and CRP. ${ }^{17}$ The land base in our analysis comprises 1.4 billion acres, representing about $74 \%$ of the total land area and $91 \%$ of non-Federal land in the 48 contiguous States. Further details on the NRI data are provided in the Data Appendix.

The matrix of land-use changes in Table 1 illustrates the information provided by the NRI on the disposition of land across major uses over time. Land units generally remain in the same use. For example, of land parcels cropped in 1982, 84.2\% remained in crops in 1997, while

\footnotetext{
${ }^{16}$ Beginning in 2001, the NRI has been conducted annually on a smaller sample of points. Micro-data from the annual NRI are not publicly available to date and were not used in our analysis.

${ }^{17}$ Public lands and transportation infrastructure are excluded from the analysis, as changes in these uses are not affected directly by utility maximization by private landowners. We omit water bodies and barren lands as these
} 
7.3\% had been converted to CRP, $4.6 \%$ to pasture, $1.6 \%$ to urban use, $1.3 \%$ to forest, and $0.9 \%$ to range. Of land parcels forested in 1982, 95.4\% remained in forests in 1997, while $2.5 \%$ had been converted to urban use, $1 \%$ to pasture, $0.5 \%$ to crops, another $0.5 \%$ to range, and $0 \%$ to CRP. The urban land-use category appears to be an absorbing state, with lands almost never converted from urban to non-urban uses.

Our dependent variable is the choice of land use in year, $t+5$, at each NRI point, and our covariates are the land use in year $t$, the land quality rating of the point, and proxies for the expected net returns from the land-use alternatives as of year $t$. To smooth temporary shocks from weather and other factors that affect net returns in particular years, we assume that landowners use an average of the annual net returns per acre to each land use over the most recent five-year period as the basis for their expectations of future net returns. Denoting each year as $t$, we specify land-use choices observed at time $t+5$ as a function of the average land-use net returns between years $t-4$ and $t$, inclusive. ${ }^{18}$

Assembling data from a variety of private and public sources, we constructed countylevel estimates of annual financial net returns (revenues less variable cash costs per acre) for crops, pasture, forest, range, and urban uses for all 3,014 counties in the 48 contiguous States (see Data Appendix). Net returns for crops, pasture, and range are computed in annual terms given annual yields from major crops and forage. On the other hand, returns to forests and urban uses are calculated as the net present values of a perpetual stream of forest and urban returns, respectively, and then converted to a constant annualized equivalent with an assumed private

uses are unlikely to vary over time. Finally, we exclude lands classified as marshlands and "miscellaneous," because data are not available to measure net returns to these uses.

${ }^{18}$ While some information after year $t$ could be relevant for explaining subsequent changes, we only use information as of year $t$ for our net returns proxy to avoid using data from future periods as predictors of past land-use decisions. Because observations of land use are at five-year intervals, our dependent variable includes land-use changes occurring at any time between $t$ to $t+5$, and we do not know when during this period these changes occurred. 
discount rate of five percent. ${ }^{19}$ The estimates for cropland include net returns from market sales as well as direct farm program payments. ${ }^{20}$ Our measure of payments is from the Census of Agriculture and includes all direct receipts from the Federal government, excluding payments for land retirement under the CRP and Wetlands Reserve Program (WRP). These payments are excluded because we model CRP as a distinct land-use category, and CRP and WRP payments are jointly reported in the Census. Table 2 provides summary statistics on land-use net returns.

\section{ESTIMATION AND RESULTS}

We use maximum likelihood methods to estimate the parameters of the model, drawing on cross-sectional variation in the independent variables to estimate parameters for the transition probabilities from each of four starting land uses (crops, pasture, forest, and range) to each of our six ending uses (crops, pasture, forest, range, urban and CRP) during each of the temporal transitions. ${ }^{21}$ We use all of our observations on the NRI sample points in each respective land use at the start of each of the three transition periods (1982-87, 1987-92 and 1992-97), and so in total, we estimate twelve separate equations (four starting land uses in three time periods). ${ }^{22}$

The results indicate good fit of the model, and are consistent with the expected economic relationships. ${ }^{23}$ For brevity, Table 3 reports elasticities, rather than estimated parameters for the

${ }^{19}$ Annualized returns are thus $r^{*} N P V$ where $N P V=\sum_{t=0}^{\infty} \frac{R_{t}}{(1+r)^{t}}$ and $\mathrm{r}=0.05$.

${ }^{20}$ We assume landowners are indifferent between a dollar from the government and a dollar from the market. We conjecture that farmers' expectations of future returns are approximately static with respect to the sum of market net returns and government payments, rather than to these income streams individually, given that Federal farm program payments are highly countercyclical, partially insuring market risks (Roberts, Osteen and Soule 2004).

${ }^{21}$ We also estimated models with pooled data and found that estimates based on separate cross-sections were superior at replicating land-use changes over these time periods (Lubowski 2002).

${ }^{22}$ Because land virtually never transitions out of urban uses, we do not model these potential land-use changes and, in the simulations, assume land parcels remain urbanized with $100 \%$ probability. We estimated our model for points starting in CRP over 1992-97 but not 1982-87 or 1987-92. Some land became eligible to exit the program in 1996 and changed to other uses by 1997. Other research models this post-CRP land use (Roberts and Lubowski 2007).

${ }^{23}$ Pseudo $\mathrm{R}^{2}$ values range from 0.71 to 0.95 for the different equations. The positive and significant estimates of the inclusive value parameters and tests (Hausman and McFadden 1984) of a simpler, non-nested logit model with the 
twelve equations. ${ }^{24}$ For each starting use, we report the estimated elasticity for the probability of choosing each land-use alternative with respect to the net returns to that alternative ("own return elasticities”). These elasticities indicate the percentage change in the probability of a particular land-use change for a $1 \%$ change in the corresponding net returns. In 35 out of 60 cases, the own-return elasticities are positive and significant at the 0.05 level. In the seven cases where the own-return elasticities are negative, they are never significantly different from zero at the 0.05 level. The "cross-elasticities" are the elasticities of the probability of choosing a particular use $j$ with respect to the profits of a different use $k$. In all but four of 300 cases, the cross-elasticities (not reported) are opposite in sign to the own-return elasticities and thus usually negative.

The elasticities indicate that landowners starting with lands in crops or pasture responded as anticipated to net returns from alternative land uses. For land starting in range, the own-return elasticities with respect to urban net returns are positive and significant, as well as the forest net return elasticity for 1982-97. None of the other own-return elasticities for land starting in range are significantly different from zero, suggesting that range owners are relatively insensitive to the profitability of alternative uses, except for urban development. This is reasonable, given that range lands tend to be of the lowest quality and thus unsuitable for other agricultural uses.

A final econometric consideration is that land parcels located near one another may have unobserved characteristics correlated across space. If such characteristics influence land-use decisions or if local land-use choices are interdependent, error terms will be correlated across space, leading to inconsistent and inefficient parameter estimates in a logit model due to induced heteroskedasticity (McMillen 1992). A common approach for dealing with spatial

same variables are consistent with violations of the "independence of irrelevant alternatives" hypothesis, supporting the use of the less restrictive nested logit specification. However, the nested specification was not critical for our overall findings, as the non-nested model yielded qualitatively similar results in our land-use simulations.

${ }^{24}$ Parameter estimates are reported in Lubowski (2002), and are available from the authors upon request. 
autocorrelation is to estimate a model with a spatial weight matrix that relates the error terms in each location to error terms in all the other locations. In the context of discrete dependent variable models, this approach is very computationally intensive and has only been applied to small data sets (e.g., Carrion-Flores and Irwin 2004). We explored the potential importance of spatial dependence by eliminating observations near to one another, an alternative method adopted in previous discrete choice land-use models (Nelson and Hellerstein 1997; Nelson, Harris, and Stone 2001; Cropper, Puri, and Griffiths 2001). Estimates with samples that included only a single point within each NRI primary sampling area produced results similar to estimates including all points, suggesting that spatial dependence is not a critical concern. ${ }^{25}$

\section{SIMULATIONS}

In order to explore the relative importance of factors affecting land use, we simulate nationwide changes in landowners' willingness to supply land in different uses using fitted values of land-use change probabilities derived from the econometric model. These simulations estimate changes in land allocation at the parcel-level given hypothetical exogenous changes in land-use incentives. Aggregating these individual responses yields an estimate of changes in the national supply of land in alternative uses under various counterfactual scenarios for government payments and market net returns. These simulations suggest the direction of impacts and the relative importance of different factors affecting national land use.

\section{Simulation Scenarios}

\footnotetext{
${ }^{25}$ Because the precise location of each point is not disclosed to preserve confidentiality, there is no way to directly test for spatial autocorrelation in a model with NRI point data. However, NRI's stratified sampling design provides some information on spatial relationships. Data on urban and water areas are collected for about 300,000 primary sampling areas varying from 40 to 640 acres in size. More detailed land characteristics and use data are collected at two to three points randomly selected within each of these areas (Nusser and Goebel 1997). Restricting our sample to one point within each of these clusters excludes points potentially on the same parcel or otherwise likely to share features related to location that might affect land-use choices.
} 
We simulate a factual and eight counterfactual scenarios (Table 4). The "factual" simulation uses the historically observed values of all variables and provides a baseline with which to compare land-use changes under the counterfactual scenarios. The counterfactual scenarios differ in the levels of land-use net returns used to compute transition probabilities. In each counterfactual, we fix a particular variable at a hypothetical level, keeping all other variables at their actual historical values, so as to identify the effects of individual factors on the supply of land in each use. These simulations illustrate how landowners would have responded if equilibrium net returns incentives had been different as a result of an exogenous market or policy change.

Comparing the factual simulation with counterfactuals in which particular variables are held constant at 1978 levels allows us to isolate the effects on land-use decisions of changes in those variables that occurred over the period of analysis, assuming all else had remained constant. $^{26}$ For example, the scenario "No Change in Crop Market Returns” holds the marketcomponent of cropland net returns at 1978 levels, while allowing government payments and all other variables to take on their historically observed values. By comparing the results with the factual simulation, we can estimate what impact changing crop market returns had on land allocation decisions. In addition to scenarios examining market-driven changes in net returns, we explore the influence of key government policies through additional scenarios: No Change in Government Payments; No Government Payments; No Conservation Reserve Program; ${ }^{27}$ and No Government Payments and No CRP.

\footnotetext{
${ }^{26}$ Table 2 lists the estimated mean annual net returns per acre over the different time periods and the absolute and percentage changes subsequent to 1978. Landowners are assumed to consider the average of 1978-82 values when choosing land-use over the first transition period (1982-87).

${ }^{27}$ We keep all variables at historically-observed values, but remove CRP as a land-use option by zeroing the terms in equation 3 for $k=\mathrm{CRP}$. This yields a zero probability of choosing CRP and reallocates the probability to the remaining alternatives, accounting for differences in substitutability over choice sets as allowed by the nested model.
} 
The simulations indicate the impact of each factor examined on the national supply of land in each use. Aggregating individual decisions to supply land for a particular use given an exogenous change in the net returns to that use yields an estimate of movements along the national supply curve for that land-use alternative. For example, our simulated changes in cropland under the scenario No Change in Crop Market Returns indicate movements along the national supply curve for cropland given a shift in cropland demand. At the same time, more or less cropland supplied will reduce or increase, respectively, the amount of land available for pasture, forests, and all other alternatives. Our estimates of these changes thus represent an inward or outward shift in the land supply curve for each of these other uses.

The estimated impacts on land supply from our simulations are not equivalent to estimated changes in equilibrium land use at the intersection of both supply and demand as determined simultaneously. If crop prices had remained at their relatively high 1978 levels, for instance, less land might have shifted from crops to alternative uses, lowering the production and raising the prices of pasture, range, and forest products. As a result, this would likely have produced a different set of incentives and resulting land-use allocation compared to our simulation.

If such price feedbacks are significant, our simulation results will overstate the absolute equilibrium impacts from the different market and policy factors, but still reflect the relative ranking of effects at a first order of approximation. Larger shifts in the supply of land in a particular use will induce greater movements along a downward sloping demand curve for land in that use, producing larger changes in the price for that land use. If limited to a single sector that is, price feedbacks affecting land use A are mainly effects on the net returns to use A these feedbacks would attenuate the equilibrium land-use impacts from each factor but still 
preserve our estimates for the relative ranking of these effects. Large enough price feedbacks on the net returns to other uses, however, could potentially alter these rankings. Changes in the net returns to land use B (e.g. range) might have very small direct effects on the acreage and/or price of land use A (e.g. crops), but have effects on the price of land use C (e.g. pasture) which in turn have large impacts on land in use A. The likelihood of such indirect effects will depend on the relative elasticities of supply and demand for the different uses, namely the response of acreage (and thus net returns) from C to changes in net returns from B and the relative sensitivity of land use A to the net returns from C.

Although we do not model price feedbacks, our simulations reveal the major pathways along which market and policy changes have affected land supply in each use and the relative impacts on land supply in other uses. This information provides a gauge for when different feedback effects may potentially be significant, depending on the relevant elasticities of demand. To reduce potentially confounding influences from price feedbacks, we also examine changes in land allocation in response to smaller changes in our market and policy drivers.

As a sensitivity test, we simulate scenarios in which the changes in net returns and government programs are reduced by just 5 percent relative to historical levels. For example, we simulate 5 Percent Less Change in Crop Market Return where the absolute change since 1978 is reduced by just 5 percent in each period relative to the factual simulation. This change is onetwentieth compared to that in No Change in Crop Market Returns where, as already described, the change in crop market net returns is set at zero (a 100-percent reduction from the historical levels of change). ${ }^{28}$ Because the nested logit land-use change probabilities are nonlinear

\footnotetext{
${ }^{28}$ Five Percent Less Government Payments and 5 Percent Less CRP are scenarios with total payments (in each period) and total CRP enrollment (in 1997) reduced by 5 percent, respectively To simulate 5 percent less land in CRP by 1997, we keep all variables at historically observed levels, but scale the component of the utility function for the CRP alternative so as to achieve the acreage target. This can be viewed as a reduction in total CRP
} 
functions of each exogenous variable, the relative magnitudes of the estimated effects can vary even as all variables are scaled down equally. Examining smaller levels of changes provide estimates of the marginal rather than overall impacts of the different factors affecting national land-use changes from 1982 to 1997.

\section{Simulation Methods}

Using the estimated coefficients from our econometric model, land-use change probabilities are calculated for each NRI point and each transition period, using point-level data on land use and land quality together with county-level data on net returns. We begin the simulations in 1982 with each NRI point in the land use reported for 1982. We multiply the acreage weight for the point by the estimated 1982-87 transition probabilities for the corresponding initial land use to produce an estimate of the area that converts from 1982 to 1987 from the initial land use to each of the six potential land uses, including the status quo. We then multiply these predictions of land use in 1987 by the corresponding 1987-92 probabilities to estimate land-use changes from 1987 to 1992; and we multiply the acreage predictions for 1992 by the estimated 1992-97 probabilities to estimate changes from 1992 to 1997 . Summing the predicted acres in each land use in 1997 across all the points provides estimates of land-use totals for the 48 contiguous States in the final year of the simulations.

\section{Simulation Results}

The simulation model performs well in reproducing the direction and relative magnitudes of land-use changes during the period of analysis. The factually-simulated 1997 land uses are within $1 \%$ of actual totals for each land use, except in the case of urban land, for which the

incentives, net of conversion costs, applied in equal proportion across all land quality types and time periods. For the combined scenario 5 Percent Less Government Payments and 5 Percent Less CRP, the utility from CRP needed to be further scaled back to reduce CRP acreage by 5 percent given the reduced incentives for cropland use. 
factual estimate is within $2 \%$ of the actual value. ${ }^{29}$ The results in Tables 5 through 10 indicate the relative importance of the factors examined in the different scenarios in driving acreage changes for each land-use category across the 48 contiguous States over 1982-97. The first column of each table contains the simulated acreage change under each scenario, providing an estimate of the impact on the national supply of land in that use. The second column indicates this acreage change as a share of the factually-simulated acreage change. The third column reports the difference between the counterfactual and factual acreage change as a percentage of the factual acreage change. This provides an estimate of the maximum share of the historically observed change that can be attributed to each factor in the absence of attenuating price feedbacks. Comparing the magnitudes of these values across rows provides an estimate of the relative importance of the different market and policy factors affecting national land use.

The ranking of these factors' importance is robust to smaller-sized changes which are unlikely to involve price feedbacks. As reported in the footnotes to Tables 5-10, the relative ranking is virtually unchanged if we scale down the historical changes by only 5 (rather than 100) percent. Thus, in general, results from our simulations based on the larger changes also convey the relative importance from more marginal changes in the different factors affecting national land use from 1982 to 1997 . One exception is the relative importance of forest net returns in driving changes in forestland and, by extension, rangeland, as described further below. Cropland.

In the case of cropland (Table 5), the introduction of CRP followed by declining crop market conditions were the most important determinants of the decrease in cropland observed between 1982 and 1997. Disaggregated results indicate that the decline in crop net returns

\footnotetext{
${ }^{29}$ Simulated land-use changes are also in line with the NRI. For 1982-97, the NRI indicates that crop, pasture, and range areas decreased by $10.44 \%, 8.91 \%$, and $2.59 \%$, while forest and urban acres increased by $0.88 \%$ and $47.19 \%$,
} 
chiefly induced land to leave crop production, while also discouraging the entry of new cropland, shifting the supply of cropland by an estimated 10.7 million and 6.9 million acres, respectively. The change in crop net returns principally affected land at the margins with pasture and the CRP. While falling crop net returns spurred landowners to leave crop production, government farm payments played a role in blunting the effect of market forces. The sum of all government payments offset an estimated 42\% of the decline induced by crop markets, increasing 1997 cropland by a maximum of 7.5 million acres or $2 \%$ in the absence of price feedbacks. The disaggregated results indicate that government payments boosted crop acreage chiefly by increasing the retention of existing cropland, rather than by bringing new land into cultivation.

The land-use effects of government payments that raised the profitability of cropland were dwarfed by the success of the CRP in retiring cropland over 1982-97. The estimated combined effect of CRP and direct Federal farm program payments was to reduce 1997 cropland supply by 24.8 million acres or almost 7 percent. The CRP accounts for an estimated 29.3 million acre (8 percent) decline in cropland supply from 1982 to 1997 or as much as $71 \%$ of the decline in crop acres during this period without any price feedbacks. This suggests that approximately 91\% of land in CRP in 1997 constituted additional reductions in crop acreage over and above the decrease that would have occurred in the absence of the program. ${ }^{30}$

The decline in pasture net returns after 1978 also appears to have been a significant factor restraining the crop area decrease, with an estimated effect on cropland supply equivalent to that of all direct government payments. Other factors had only minor estimated impacts on the

respectively. Our corresponding factually-simulated changes are $9.82 \%, 8.30 \%$, and $1.93 \%$, and $0.46 \%$ and $49.70 \%$.

${ }^{30}$ The fact that some fraction of CRP land may have exited crop production even without the program is distinct from the notion of "slippage," the possibility that crop acreage reductions in CRP might be offset by induced increases in cropland in other areas (Wu 2000; Roberts and Bucholtz 2005). 
supply of cropland. Changes in forest net returns restrained the decline in cropland by an estimated 3.4\%, while changes in urban returns increased the decline by an estimated $1.5 \%$.

\section{$\underline{\text { CRP and Pasture }}$}

The key determinants of CRP enrollment were changes in cropland net returns (Table 6), while government payments also reduced incentives for CRP enrollment. ${ }^{31}$ The observed decline in pasture area was partly due to decreases in pasture net returns, but this was less important than the decrease in crop net returns, which restrained the decline in pasture acres (Table 7). Government policies also had significant impacts on pasture acreage. Both government payments and the CRP raised incentives for non-pasture land uses, promoting the decline in pasture acres. The CRP reduced pasture acres by diverting cropland that would have converted to pasture in the absence of the program. To the extent that CRP was a dominant factor behind the decline in cropland, it may have had a positive influence on cropland net returns, an important determinant of pasture acreage. Through this indirect feedback, CRP may have had an additional effect on reducing pastureland that we do not measure.

\section{Forests and Range}

In the case of forest land, the rise in forest net returns after 1978 was the most important factor affecting changes in supply (Table 8). The rise in forest net returns had a greater influence reducing acreage changes from forests rather than increasing conversions of land into new forests. The decline in crop net returns after 1978 also had an important influence on forestland change. In addition, the rise in urban net returns was an important factor affecting forest area changes, restraining forest increases. Government policies also influenced forestland changes by

\footnotetext{
${ }^{31}$ Although illustrative of the direction and relative magnitude of the impacts of factors, our results should not be interpreted as realistic estimates of total CRP acres under the different scenarios. In the simulations, the policies governing the program are held constant and the government is assumed to accept acres of each quality into CRP
} 
increasing incentives for alternative land uses. As noted in the case of pasture, to the extent that the CRP raised cropland net returns, the program may also have had an indirect effect on reducing forestland that is not captured by our estimates.

In the case of range acreage, the observed decline was mainly induced by increases in forest net returns after 1978, which accounted for up to $50 \%$ of the range area decrease (Table 9). Declines in pasture net returns and crop returns restrained the decline in rangeland, while the rise in urban net returns increased it. Other factors are estimated to have minor effects on rangeland. If changes in crop net returns and government payments reduced forest area enough to raise forest net returns, however, these factors could have had an additional negative effect on rangeland acres.

When we examine the smaller scenarios entailing a 5-percent reduction from the historical trend, the change in forest net returns declines from being the highest ranked factor driving the forest acreage change to second-to-last in importance behind the change in rangeland net returns. Because this smaller impact on forest acres means less land is diverted from range at the margin, the relative importance of forest net returns on the change in rangeland acreage also declines compared to the scenarios with the full-scale changes.

\section{$\underline{\text { Urban Areas }}$}

Urban areas increased by nearly $50 \%$ in the factual simulation (Table 10). The only substantial driver of this urban expansion was the increase in urban net returns, which accounted for as much as $13 \%$ of the increase in urban land area. ${ }^{32}$ We estimate that the decline in crop net

with the same historically-observed probability, allowing total acreage to expand and contract according to the amount of land offered for enrollment.

${ }^{32}$ The relatively low explanatory power of the urban net return variable could be a result of the coarseness of our data. While our measure of urban net returns is at the county level, there is a great deal of within-county variation in development potential that our measures do not capture. 
returns boosted the increase by a maximum of $2 \%$, while other factors had trivial effects, affecting the change in urban areas by less than $1 \%$ overall.

\section{CONCLUSIONS}

The econometric and simulation analyses demonstrate that private land-use decisions have depended critically on land quality and have been steered by anticipated economic returns to alternative uses, which in some cases have been affected significantly by public policies, sometimes intentionally and sometimes unintentionally. The evidence is strong that cropland declines over the past two decades have been due to falling crop net returns and the existence of the Conservation Reserve Program (CRP), as has been suggested by other research (Vesterby and Krupa 1995; Alig, Dicks, and Moulton 1998). We have also isolated the opposing influences of the CRP and other Federal farm payments. By raising the profitability of cropland, the government increased acreage in crops and directly competed with itself in providing incentives for landowners to retire environmentally-sensitive cropland under the CRP. The increase in cropland area also came largely at the expense of land in pasture. Because cropping is a more intensive land use, typically involving greater application of agricultural chemicals, government payments are likely to have had unintended environmental impacts.

Apart from environmental impacts, the effect of government programs on aggregate crop production is a critical issue for on-going deliberations on global trade liberalization. ${ }^{33}$ We estimated the contribution of CRP and direct Federal payments, two major elements of U.S. farm policy, to aggregate crop production. ${ }^{34}$ Excluding CRP and WRP, direct Federal payments to

\footnotetext{
${ }^{33}$ Federal farm payments under CRP and other environmental programs are currently permitted by WTO rules under the "green box" exemption if they are deemed "minimally trade distorting." On the other hand, trade-distorting impacts of direct payments are potentially actionable, regardless of countervailing impacts from other programs.

${ }^{34}$ We did not examine the effects of agricultural tariffs or the influence of indirect Federal assistance to farmers, such as subsidized crop insurance through private firms, or Federal funding of agricultural research or other thirdparty activities. Hoekman, Ng and Olearraga (2002) estimate that agricultural tariffs worldwide have had more than
} 
farmers increased land in crops by as much as 2 percent in 1997, partially offsetting the acreage decline due to the change in crop commodity markets. Our results also indicate that the positive effects on crop acres of direct Federal payments to farmers were more than offset by cropland retirement under the CRP. ${ }^{35}$

For forest areas, we identified the rise in timber net returns as the most important factor driving the increase in forest areas between 1982 and 1997. This is consistent with reports that the increase in forests largely involved timberland acreage (Anderson and Magleby 1997; Alig, Dicks, and Moulton 1998). We also identified declining crop net returns as a major factor affecting forest area during this period, which is consistent with reports that forest areas have increased due to passive regrowth on abandoned agricultural lands (Alig and Wear 1992; Anderson and Magleby 1997; Alig, Dicks, and Moulton 1997; Flather, Brady, and Knowles 1999). Our findings suggest that policies targeting forest net returns, such as payments for carbon sequestration, are likely to be particularly effective at encouraging the retention of existing forests, rather than new forest establishment, as others have also suggested (Newell and Stavins 2000). ${ }^{36}$ We also find that the marginal impact of forest net returns on forestland acreage is sensitive to the level of the simulated changes, suggesting that policies targeting forest net returns may be relatively ineffectual until the change in incentives exceeds a critical threshold. Urban net returns appear as the only significant driver of urban land increases, supporting the notion that the dramatic increase in urban land observed subsequent to 1982 was largely a

twice the impact on trade flows as domestic support policies. Lubowski et al. (2006a) estimate that crop insurance subsidy increases after 1994 raised cultivated acreage in 1997 by about 1 percent, with disproportionate impacts on wetlands and other environmentally sensitive lands.

${ }^{35}$ Our estimates for the historic impact of direct government payments on crop acreage lie the middle to upper range of other studies (Westcott and Price 2001; FAPRI 2001). Previous studies have also estimated offsetting effects of CRP and direct Federal farm payments under recent Farm Acts (Gardner 2002; Westcott, Young, and Price 2002).

${ }^{36}$ This conclusion could vary regionally. In contrast to our national-level results, Plantinga and Ahn (2002) estimate that in the U.S. South Central region policies to convert land to forests would be less costly than policies to retain existing forests. 
response to increased housing demand driven by demographic changes and economic growth (Heimlich and Anderson 2001). Our findings suggest that efforts to protect open space by increasing net returns to agricultural uses are likely to have only limited impacts. Once urban development becomes feasible, development returns are so much greater than returns to other land uses that observed changes in non-urban returns are of insufficient magnitude to make a significant difference. This may explain why use-value assessments and other preferential tax policies, employed in virtually all States to encourage the retention of cropland, have had minimal effects in restraining urban development (Heimlich and Anderson 2001). This suggests that more targeted and aggressive policies would be needed to reduce urbanization, such as land purchases, acquisition of development rights, and substantial development charges.

This study demonstrates the importance of modeling land-use change in a framework that incorporates changes among all major land-use alternatives. With the notable exception of urban land, our findings highlight the importance of net returns to a variety of land-use categories as determinants of land area change for particular uses. The results indicate the margins that are most active for particular land-use categories and the variables that consequently have the greatest influence on the area allocated to these uses. These factors represent the most powerful market-based mechanisms for the government to influence land-use changes either unintentionally or through deliberate policy interventions. 


\section{DATA APPENDIX}

Land Use: Our data on land use is from USDA National Resources Inventory (NRI). “Cropland” includes row and close-grown crops, fallow, pasture and haylands in rotation with crops, permanent haylands, vineyards, orchards, and nurseries. "Pasture” includes land managed for introduced forage for livestock grazing. "Range” includes land under native or introduced forage suitable for grazing which receives only limited management. "Forests" are areas at least one acre in size and 100 feet in width that are least 10 percent stocked with trees with the potential to reach 13 feet at maturity. This translates to a canopy cover of at least 25 percent. “Urban lands” include areas in residential, industrial, commercial, or institutional uses. Parcels below ten acres, such as small parks and transport facilities, are also classed as urban if they are completely surrounded by urban lands. This definition excludes roads and other lands used for transportation in non-metropolitan areas, as these are separately identified by the NRI.

Crop Market Net Returns: Data on prices, yields, cash costs, and acres are used to compute weighted county-level market net returns for 21 major crops. State-level marketing-year-average prices and county-level yields are from the National Agricultural Statistics Service (NASS). Data on cash costs as a share of revenue at the state and regional level, respectively, are from the Census of Agriculture and the Economic Research Service’s (ERS). County acreage from NASS and the Census of Agriculture provided weights for averaging across individual crops.

Government Payments: County-level estimates of total Federal program payments per acre are from the Census of Agriculture and include receipts from deficiency payments, support price payments, indemnity programs, disaster payments, and payments for soil and water conservation projects. Conservation Reserve and Wetlands Reserve program payments are excluded.

Pasture Net Returns: Annual net returns per acre for pasture are estimated using pasture yields 
from the SOILS-5 database linked to the NRI, state prices for "other hay" from NASS, and per acre costs for hay and other field crops from the Census of Agriculture.

Range Net Returns: Annual rangeland net returns per acre are computed with forage yields from SOILS-5 and state-level per head grazing rates for private lands from ERS.

Forest Net Returns: We use a 5 percent interest rate to annualize the estimated net present value of a weighted average of sawtimber revenues from different forest types based on prices, yields, costs, and acres. State-level stumpage prices were gathered from state and Federal agencies and private data services. Regional merchantable timber yield estimates for different forest types were obtained from Richard Birdsey of the U.S. Forest Service. Regional replanting and annual management costs were derived from Moulton and Richards (1990) and Dubois, McNabb and Straka (1999). The Faustmann formula was used to compute the optimal rotation age, assuming forests start newly planted at year zero. County acreage and timber output data from the Forest Inventory and Analysis (FIA) and Timber Product Output (TPO) surveys of the U.S. Forest Service provided weights for averaging across individual forest types and species, respectively.

Urban Net Returns: Annual urban net returns per acre are estimated as the median value of a recently-developed parcel, less the value of structures, annualized at a 5 percent interest rate. Median county-level prices for single family homes were constructed from the decennial Census of Population and Housing Public Use Microdata Samples and the Office of Federal Housing Enterprise Oversight (OFHEO) House Price Index. Regional data on lot sizes and the value of land relative to structures for single-family homes were from the Characteristics of New Housing Reports (C-25 series) and the Survey of Construction (SOC) micro data from the Census Bureau.

Additional data descriptions are provided in Lubowski (2002) and are available upon request. 


\section{REFERENCES}

Adams, Darius M., Rarlph J. Alig, Bruce A. McCarl, John M. Callaway, Steven M. Winnett. 1999. "Minimum Cost Strategies for Sequestering Carbon in Forests." Land Economics 75(3): 360-374.

Alig, Ralph J., Darius M. Adams, and Bruce McCarl. 1998. "Impacts of Incorporating Land Exchanges between Forestry and Agriculture in Sector Models.” Journal of Agricultural and Applied Economics 30(2): 389-401.

Alig, Ralph J., Darius M. Adams, Bruce McCarl, J.M.Callaway, and Steven Winnett. 1997. "Assessing Effects of Mitigation Strategies for Global Climate Change with an Intertemporal Model of the U.S. Forest and Agriculture Sectors.” Environmental and Resource Economics 9: 259-274.

Alig, Ralph J., Michael R. Dicks, and Robert J. Moulton. 1998. "Land-Use Dynamics Involving Forestland: Trends in the U.S. South.” In Kluender, R.A., N.B. Smith and M. M. Corrigan, Proceedings of the 1988 Southern Forest Economics Workers Meeting: 9-23. University of Arkansas: Moticello, AR.

Alig, Ralph J. and Robert G. Healy. 1987. "Urban and Built-Up Land Area Changes in the United States.” Land Economics 63(3): 215-226.

Alig, Ralph J. and David N. Wear. 1992. "Changes in Private Timberland: Statistics and Projections for 1952 to 2040." Journal of Forestry 90(5): 31-37.

Anderson, Margot and Richard Magleby. 1997. "Agricultural and Environmental Indicators, 1996-97.” Agricultural Handbook No. 712, U.S. Department of Agriculture, Economic Research Service: Washington, D.C.

Ben-Akiva, Moshe and Steven R. Lerman. 2000. Discrete Choice Analysis: Theory and Application to Travel Demand. The MIT Press: Cambridge, MA

Bockstael, Nancy E. and Elena G. Irwin. 2000. "Economics and the Land Use-Environment Link." The International Yearbook of Environmental and Resource Economics. Edward Elgar Publishing, H. Folmer and T. Tietenberg, editors.

Carrion-Flores, Carmen and Elena G. Irwin. 2004. "Determinants of Residential Land-Use Conversion and Sprawl at the Rural-Urban Fringe.” American Journal of Agricultural Economics 86(4): 889-904.

Cropper, Maureen, Jyotsna Puri, and Charles Griffiths. 2001. "Predicting the Location of Deforestation: The Role of Roads and Protected Areas in North Thailand.” Land Economics 77(2): 172-186.

Dixit, Avinash K. and Robert S. Pindyck. 1994. Investment under Uncertainty. Princeton University Press: Princeton, NJ.

Dubois, Mark R., Kenneth McNabb and Thomas J. Straka. 1999. "Cost Trends for Forestry Practices in the South." Forest Farmer 32: 3-8.

Farm Service Agency (FSA), U.S. Department of Agriculture. 2006. Conservation Reserve Program, Monthly Summary - July 2006. Washington, D.C. 
Food and Agricultural Policy Research Institute (FAPRI). 2001. "Analysis of the Grain, Oilseed, and Cotton Provisions of the Agricultural Act of 2001, H.R. 2646.” FAPRI-UMC Report No. 09-01. FAPRI, University of Missouri: Columbia, MO.

Flather, C. H., S. J. Brady, and M. S. Knowles. 1999. "Wildlife resource trends in the United States: A technical document supporting the 2000 USDA Forest Service RPA Assessment.” General Technical Report No. 33. U.S. Department of Agriculture Forest Service, Rocky Mountain Research Station: Ft. Collins, CO.

Gardner, Bruce. 2002. "North American Agricultural Policies and Effects on Western Hemisphere Markets since 1995, with a Focus on Grains and Oilseeds.” Department of Agricultural and Resource Economics Working Paper No. 02-12. The University of Maryland: College Park, MD.

Greene, William H. 2000. Econometric Analysis, 4th ed. Prentice Hall: Upper Saddle River, NJ.

Hausman, Jerry and Daniel McFadden. 1984. "Specification Tests for the Multinomial Logit Model.” Econometrica 52(5): 1219-40.

Heimlich, Ralph E. and William D. Anderson. 2001. Development at the Urban Fringe and Beyond: Impacts on Agriculture and Rural Land. Agricultural Economic Report No. 803, U.S. Department of Agriculture, Economic Research Service: Washington, D.C.

Heimlich, Ralph E., Keith D. Wiebe, Roger Claassen, Dwight Gadsby, and Robert M. House. Wetlands and Agriculture: Private Interests and Public Benefits. Agricultural Economics Report No. (AER 765), U.S. Department of Agriculture, Economic Research Service: Washington, D.C.

Helms, Douglas. 1992. Readings in the History of the Soil Conservation Service. U.S. Department of Agriculture, Soil Conservation Service. Washington, DC.

Hoekman, Bernard, Francis Ng and Marcelo Olarreaga. 2002. "Reducing Agricultural Tariffs Versus Domestic Support: What's More Important for Developing Countries?” World Bank Policy Research Working Paper, No. 2918. World Bank: Washington, D.C.

Lubowski, Ruben N. 2002. Determinants of Land-Use Transitions in the United States: Econometric Analysis of Changes among the Major Land-Use Categories. Ph.D. Dissertation. Harvard University, Cambridge, MA.

Lubowski, Ruben N., Shawn Bucholtz, Roger Claassen, Michael J. Roberts, Joseph C. Cooper, Anna Gueorguieva, and Robert Johansson. 2006a. Environmental Effects of Agricultural Land-Use Change: The Role of Economics and Policy. Economic Research Report No. 25, U.S. Department of Agriculture, Economic Research Service: Washington, D.C.

Lubowski, Ruben N., Marlow Vesterby, Shawn Bucholtz, Alba Baez, and Michael J. Roberts. 2006b. Major Uses of Land in the United States, 2002. Economic Information Bulletin No. 14, U.S. Department of Agriculture Economic Research Service. Washington, DC.

McCarl, Bruce A. and Uwe A. Schneider. 2001. "Greenhouse Gas Mitigation in U.S. Agriculture and Forestry.” Science 294: 2481-2482.

McMillen, Daniel P. 1992. "Probit with Spatial Autocorrelation.” Journal of Regional Science 32(3): 335-348. 
Moulton, Robert J. and Kenneth R. Richards. 1990. "Costs of Sequestering Carbon through Tree Planting and Forest Management in the United States.” GTR WO-58. Washington, D.C.: U.S. Department of Agriculture, Forest Service.

Nelson, Gerald C. and Daniel Hellerstein. 1997. "Do Roads Cause Deforestation? Using Satellite Images in Econometric Analysis of Land Use.” American Journal of Agricultural Economics 79: 80-88.

Nelson, G.C., Harris, Virginia, and Steven W. Stone. 2001. "Deforestation, Land Use, and Property Rights: Empirical Evidence from Darien, Panama.” Land Economics 77(2): 187205.

Newell, Richard G. and Robert N. Stavins. 2000. “Climate Change and Forest Sinks: Factors Affecting the Costs of Carbon Sequestration.” Journal of Environmental Economics and Management 40(3): 211-235.

Nusser, S.M. and J.J. Goebel. 1997. "The National Resources Inventory: A Long-Term MultiResource Monitoring Programme." Environmental and Ecological Statistics 4(3): 181204.

Oxfam International, 2003. “Cultivating Poverty: The Impact of US Cotton Subsides on Africa.” Oxfam Briefing Paper 30. Boston, MA.

Parks, Peter J. and Randall A. Kramer. 1995. "A Policy Simulation of the Wetlands Reserve Program." Journal of Environmental Economics and Management 28: 223-240.

Pew Center for Civic Journalism. 2000. "Research - Straight Talk from Americans - 2000.” www.pewcenter.org/doingcj/research/r_ST2000nat1.html.

Plantinga, Andrew J., and SoEun Ahn. 2002. "Efficient Policies for Environmental Protection: An Econometric Analysis of Incentives for Land Conversion and Retention.” Journal of Agricultural and Resource Economics 27(1): 128-145.

Plantinga, Andrew J., Ralph Alig, and Hsiang-tai Cheng. 2001. "The Supply of Land for Conservation Uses: Evidence from the Conservation Reserve Program.” Resources, Conservation and Recycling 31: 199-215.

Plantinga, Andrew J. and Joseph Buongiorno. 1990. "Determinants of Changes in Non-Industrial Private Timberland Ownership in the United States.” Journal of World Forest Resource Management 5: 29-46.

Roberts, Michael J. and Shawn Bucholtz. 2005. "Slippage in the Conservation Reserve Program or Spurious Correlation? A Comment.” American Journal of Agricultural Economics 87(1): 244-250.

Roberts, Michael and Ruben Lubowski. 2007. "Enduring Impacts of Land Retirement Policies: Evidence from the Conservation Reserve Program.” Land Economics, forthcoming (November).

Roberts, Michael J., Craig Osteen, and Meredith Soule. 2004. Risk, Government Programs, and the Environment. Technical Bulletin No. 1908. U.S. Department of Agriculture, Economic Research Service: Washington, D.C. 
Rust, John. 1987. "Optimal Replacement of GMC Bus Engines: An Empirical Model of Harold Zurcher.” Econometrica 55(5): 999-1033.

Schatzki, Todd. 2003. “Options, Uncertainty, and Sunk Costs: An Empirical Analysis of Land Use Change.” Journal of Environmental Economics and Management 46: 86-105.

Smith, Brad W., Patrick D. Miles, John S. Vissage, and Scott A. Pugh. 2004. Forest Resources of the United States, 2002: A Technical Document Supporting the USDA Forest Service 2005 Update of the RPA Assessment. General Technical Report NC-241. Forest Service, North Central Research Station, U.S. Department of Agriculture, St. Paul, MN.

Soil Survey Staff. 2000. Soil Ratings for Plant Growth-A System for Arraying Soils According to their Inherent Productivity and Suitability for Crops. C.S. Holzhey and H.R. Sinclair, eds. U.S. Department of Agriculture, Natural Resources Conservation Service, National Soil Survey Center. Lincoln, NE.

Stavins, Robert N. 1999. “The Costs of Carbon Sequestration: A Revealed-Preference Approach.” American Economic Review 89(4): 994-1009.

Stavins, Robert N. and Adam B. Jaffe. 1990. "Unintended Impacts of Public Investments on Private Decisions: The Depletion of Forested Wetlands." American Economic Review 80(3): 337-352.

Thornes, Paul and Daniel P. Miller. 1998. "Land Value and Parcel Size: A Semiparametric Analysis.” Journal of Real Estate Finance and Economics 17(3): 233-244.

U.S. Department of Agriculture (USDA). 1973. “Land Capability Classification.” Soil Conservation Service Handbook, No. 210. Washington, DC.

U.S. Department of Agriculture Economic Research Service (ERS). 2003. “U.S. and State Farm Income Data.” http://www.ers.usda.gov/data/FarmIncome/finfidmu.html

U.S. Environmental Protection Agency (EPA). 2005. Greenhouse Gas Mitigation Potential in U.S. Forestry and Agriculture. EAP 430-R-05-006. Washington, DC.

Vesterby, Marlowe and Kenneth S. Krupa. 1995. "Major Uses of Land in the United States: 1997.” Statistical Bulletin No. 973, U.S. Department of Agriculture, Economic Research Service: Washington, D.C.

Westcott, Paul C. and J. Michael Price. 2001. "Analysis of the U.S. Commodity Loan Program with Marketing Loan Provisions.” Agricultural Economic Report No. 801. U.S. Department of Agriculture, Economic Research Service: Washington, D.C.

Westcott, Paul C., C. Edwin Young and J. Michael Price. 2002. “The 2002 Farm Act: Provisions and Implications for Commodity Markets.” Agriculture Information Bulletin No. 778. U.S. Department of Agriculture, Economic Research Service: Washington, D.C.

World Trade Organization (WT0). 2006. “Talks suspended. “Today there are only losers.”, WTO News, DDA June/July 2006 Modalities: Summary 24 July. http://www.wto.org/english/news_e/news06_e/mod06_summary_24july_e.htm

Wu, Junjie. 2000. "Slippage Effects and the Conservation Reserve Program." American Journal of Agricultural Economics 82(4): 979-992. 
Table 1. Changes in Major Non-Federal Land Uses from 1982 to 1997 in the Contiguous 48 States (1,000s of acres) ${ }^{\text {a }}$

\begin{tabular}{|c|c|c|c|c|c|c|c|}
\hline \multirow[b]{2}{*}{ Land Use in 1982} & \multicolumn{6}{|c|}{ Land Use in 1997} & \multirow{2}{*}{1982 Total } \\
\hline & Cropland & $C R P^{b}$ & Forest Land & Pastureland & Rangeland & Urban Land & \\
\hline Cropland & $\begin{array}{c}350,265 \\
84.19 \% \\
\end{array}$ & $\begin{array}{l}30,412 \\
7.31 \% \\
\end{array}$ & $\begin{array}{l}5,607 \\
1.35 \% \\
\end{array}$ & $\begin{array}{l}19,269 \\
4.63 \% \\
\end{array}$ & $\begin{array}{l}3,659 \\
0.88 \% \\
\end{array}$ & $\begin{array}{r}6,816 \\
1.64 \% \\
\end{array}$ & $\begin{array}{c}416,029 \\
100 \% \\
\end{array}$ \\
\hline Forest Land & $\begin{array}{c}2,037 \\
0.51 \% \\
\end{array}$ & $\begin{array}{l}4,168 \\
1.05 \% \\
\end{array}$ & $\begin{array}{l}380,343 \\
95.42 \% \\
\end{array}$ & $\begin{array}{l}9,803 \\
2.46 \% \\
\end{array}$ & $\begin{array}{r}2,099 \\
0.53 \% \\
\end{array}$ & $\begin{array}{c}129 \\
0.03 \% \\
\end{array}$ & $\begin{array}{c}398,579 \\
100 \% \\
\end{array}$ \\
\hline Pastureland & $\begin{array}{c}15,347 \\
11.85 \% \\
\end{array}$ & $\begin{array}{l}1,330 \\
1.03 \% \\
\end{array}$ & $\begin{array}{c}14,091 \\
10.88 \% \\
\end{array}$ & $\begin{array}{c}92,088 \\
71.12 \% \\
\end{array}$ & $\begin{array}{l}2,568 \\
1.98 \% \\
\end{array}$ & $\begin{array}{r}4,053 \\
3.13 \% \\
\end{array}$ & $\begin{array}{c}129,478 \\
100 \% \\
\end{array}$ \\
\hline Rangeland & $\begin{array}{c}6,968 \\
1.69 \% \\
\end{array}$ & $\begin{array}{c}729 \\
0.18 \% \\
\end{array}$ & $\begin{array}{c}3,022 \\
0.73 \% \\
\end{array}$ & $\begin{array}{l}3,037 \\
0.74 \% \\
\end{array}$ & $\begin{array}{l}394,617 \\
95.91 \% \\
\end{array}$ & $\begin{array}{l}3,055 \\
0.74 \% \\
\end{array}$ & $\begin{array}{c}411,427 \\
100 \%\end{array}$ \\
\hline Urban Land & $\begin{array}{c}2 \\
0.00 \% \\
\end{array}$ & $\begin{array}{c}0 \\
0.00 \% \\
\end{array}$ & $\begin{array}{c}2 \\
0.00 \% \\
\end{array}$ & $\begin{array}{c}1 \\
0.00 \% \\
\end{array}$ & $\begin{array}{c}0 \\
0.00 \% \\
\end{array}$ & $\begin{array}{r}51,946 \\
99.99 \% \\
\end{array}$ & $\begin{array}{c}51,951 \\
100 \% \\
\end{array}$ \\
\hline $1997 \mathrm{Total}^{\mathrm{C}}$ & $\begin{array}{c}376,383 \\
19.42 \%\end{array}$ & $\begin{array}{c}32,696 \\
1.69 \% \\
\end{array}$ & $\begin{array}{c}404,680 \\
20.88 \%\end{array}$ & $\begin{array}{c}119,513 \\
6.17 \%\end{array}$ & $\begin{array}{c}404,824 \\
20.89 \%\end{array}$ & $\begin{array}{l}75,924 \\
3.92 \%\end{array}$ & $\begin{array}{c}1,937,664 \\
100.00 \%\end{array}$ \\
\hline
\end{tabular}

${ }^{a}$ Read the table horizontally to see how land that was under a particular use in 1982 was subsequently allocated in 1997 . Read the table vertically to see how land that that was in a particular land use in 1997 was previously allocated in 1982. Percentages are of 1982 totals (far right column).

${ }^{\mathrm{b}}$ There is no corresponding row entry for the Conservation Reserve Program (CRP) as this Federal program was established in 1985.

${ }^{\mathrm{c}}$ In addition to the land uses reported, totals include Federal lands, water bodies, and other land-use categories not examined in this study. 
Table 2. Estimated County-Level Annual Net Returns per Acre from the Major Land Uses for the 48 Contiguous United States, 1978-1992

\begin{tabular}{|c|c|c|c|c|c|c|c|c|}
\hline \multirow{2}{*}{ Variable (\$/acre/year) ${ }^{\mathrm{a}}$} & \multicolumn{4}{|c|}{ Mean (Standard Deviation) } & \multicolumn{4}{|c|}{ Change from 1978 (\% below) } \\
\hline & 1978 & $1978-82$ & 1983-87 & $1988-92$ & 1978 & $1978-82$ & $1983-87$ & $1988-92$ \\
\hline \multirow{2}{*}{ Crop market net returns ${ }^{\mathrm{b}}$} & 102.0 & 43.2 & 52.0 & 70.6 & 0 & -58.8 & -50 & -31.4 \\
\hline & $(69.1)$ & $(34.4)$ & $(39.5)$ & $(46.6)$ & $0 \%$ & $-57.7 \%$ & $-49.0 \%$ & $-30.8 \%$ \\
\hline \multirow{2}{*}{ Government payments } & 8.7 & 15.2 & 21.8 & 12.2 & 0 & 6.5 & 13.1 & 3.5 \\
\hline & $(4.7)$ & $(7.2)$ & $(8.8)$ & $(6.0)$ & $0 \%$ & $74.3 \%$ & $149.0 \%$ & $39.6 \%$ \\
\hline \multirow{2}{*}{$\begin{array}{l}\text { Crop market plus } \\
\text { Government net returns }\end{array}$} & 110.7 & 58.4 & 73.8 & 82.8 & 0 & -52.3 & -36.9 & -27.9 \\
\hline & $(69.8)$ & $(38.4)$ & $(45.0)$ & $(48.2)$ & $0 \%$ & $-47.3 \%$ & $-33.4 \%$ & $-25.3 \%$ \\
\hline \multirow{2}{*}{ Pasture net returns } & 32.6 & 16.1 & 7.9 & 12.7 & 0 & -16.5 & -24.7 & -19.9 \\
\hline & (28.4) & $(11.3)$ & $(8.0)$ & $(9.0)$ & $0 \%$ & $-50.5 \%$ & $-75.6 \%$ & $-61.1 \%$ \\
\hline \multirow{2}{*}{ Forest net returns } & 6.4 & 6.0 & 9.0 & 17.2 & 0 & -0.4 & 2.6 & 10.8 \\
\hline & $(6.4)$ & (5.9) & $(9.0)$ & $(17.1)$ & $0 \%$ & $-7.2 \%$ & $39.7 \%$ & $166.2 \%$ \\
\hline \multirow{2}{*}{ Urban net returns } & $1,809.0$ & $1,946.3$ & $2,389.5$ & $2,348.8$ & 0 & 137.3 & 580.5 & 539.8 \\
\hline & $(1,808.9)$ & $(1,946.3)$ & $(2,389.4)$ & $(2,348.8)$ & $0 \%$ & $7.6 \%$ & $32.0 \%$ & $29.8 \%$ \\
\hline \multirow{2}{*}{ Range net returns } & 11.3 & 11.2 & 10.3 & 10.4 & 0 & -0.1 & -1 & -0.9 \\
\hline & $(10.5)$ & $(10.1)$ & $(8.9)$ & $(9.3)$ & $0 \%$ & $-1.4 \%$ & $-8.8 \%$ & $-8.0 \%$ \\
\hline
\end{tabular}

${ }^{a}$ Values are averages over each five-year period of weighted annual county-level returns (see Data Appendix). Values are in 1990 dollars, deflated using the producer price index for all commodities from the Bureau of Labor Statistics.

${ }^{\mathrm{b}}$ Includes only the market-component of crop net returns (price times yield minus variable costs).

c Includes direct Federal farm program payments per acre, excluding the Conservation and Wetlands Reserve Programs.

${ }^{\mathrm{d}}$ The sum of the market-component of crop net returns plus direct Federal farm program payments. 
Table 3. Own-Return Land-Use Choice Elasticities ${ }^{\mathrm{a}}$

\begin{tabular}{|c|c|c|c|c|c|c|c|c|c|c|c|c|c|c|c|}
\hline \multirow{3}{*}{$\begin{array}{l}\text { Initial } \\
\text { Land } \\
\text { Use }\end{array}$} & \multicolumn{15}{|c|}{ "Final Land Use and Time Period ${ }^{\mathrm{b}}$} \\
\hline & \multicolumn{3}{|c|}{ Crops } & \multicolumn{3}{|c|}{ Forest } & \multicolumn{3}{|c|}{ Pasture } & \multicolumn{3}{|c|}{ Range } & \multicolumn{3}{|c|}{ Urban } \\
\hline & 1982-87 & $1987-92$ & 1992-97 & 1982-87 & 1987-92 & 1992-97 & 1982-87 & 1987-92 & 1992-97 & 1982-87 & 1987-92 & 1992-97 & 1982-87 & 1987-92 & 1992-97 \\
\hline Crops & $\begin{array}{c}0.01^{* *} \\
(0.00)\end{array}$ & $\begin{array}{c}0.03^{* *} \\
(0.00)\end{array}$ & $\begin{array}{c}0.01^{* *} \\
(0.00)\end{array}$ & $\begin{array}{c}0.88 * * \\
(0.05)\end{array}$ & $\begin{array}{c}0.75^{* *} \\
(0.07)\end{array}$ & $\begin{array}{c}0.31 * * \\
(0.04)\end{array}$ & $\begin{array}{l}-0.00 \\
(0.03)\end{array}$ & $\begin{array}{c}0.08 * * \\
(0.02)\end{array}$ & $\begin{array}{c}0.18^{*} \\
(0.03)\end{array}$ & $\begin{array}{l}0.68 * * \\
(0.087)\end{array}$ & $\begin{array}{c}0.29 * * \\
(0.07)\end{array}$ & $\begin{array}{c}0.38 * * \\
(0.05)\end{array}$ & $\begin{array}{c}0.39 * * \\
(0.02)\end{array}$ & $\begin{array}{c}0.25 * * \\
(0.01)\end{array}$ & $\begin{array}{c}0.34 * * \\
(0.02)\end{array}$ \\
\hline Pasture & $\begin{array}{l}0.23^{* *} \\
(0.02)\end{array}$ & $\begin{array}{l}0.38 * * \\
(0.03)\end{array}$ & $\begin{array}{l}0.34^{* *} \\
(0.02)\end{array}$ & $\begin{array}{l}0.22^{* *} \\
(0.03)\end{array}$ & $\begin{array}{c}0.08 \\
(0.05)\end{array}$ & $\begin{array}{c}0.00 \\
(0.03)\end{array}$ & $\begin{array}{l}0.03 * * \\
(0.00)\end{array}$ & $\begin{array}{l}0.00 * * \\
(0.00)\end{array}$ & $\begin{array}{c}-0.01 \\
(0.01)\end{array}$ & $\begin{array}{c}0.85 * * \\
(0.13)\end{array}$ & $\begin{array}{c}0.71 * * \\
(0.17)\end{array}$ & $\begin{array}{l}1.04^{* *} \\
(0.05)\end{array}$ & $\begin{array}{c}0.43^{* *} \\
(0.05)\end{array}$ & $\begin{array}{l}0.30 * * \\
(0.03)\end{array}$ & $\begin{array}{l}0.33^{* *} \\
(0.026)\end{array}$ \\
\hline Forest & $\begin{array}{c}0.21^{* *} \\
(0.07)\end{array}$ & $\begin{array}{c}0.28 * * \\
(0.05)\end{array}$ & $\begin{array}{c}0.29 * * \\
(0.06)\end{array}$ & $\begin{array}{c}0.00 \\
(0.00)\end{array}$ & $\begin{array}{c}0.00 \\
(0.00)\end{array}$ & $\begin{array}{c}0.00 \\
(0.05)\end{array}$ & $\begin{array}{c}0.10 \\
(0.06)\end{array}$ & $\begin{array}{c}0.04 \\
(0.09)\end{array}$ & $\begin{array}{c}-0.01 \\
(0.06)\end{array}$ & $\begin{array}{c}0.28 \\
(0.23)\end{array}$ & $\begin{array}{c}-0.56 \\
(3.46)\end{array}$ & $\begin{array}{c}0.23 \\
(0.33)\end{array}$ & $\begin{array}{c}0.23^{* *} \\
(0.02)\end{array}$ & $\begin{array}{c}0.30 * * \\
(0.07)\end{array}$ & $\begin{array}{c}0.80 * * \\
(0.06)\end{array}$ \\
\hline Range & $\begin{array}{c}-0.04 \\
(0.05)\end{array}$ & $\begin{array}{c}0.35 \\
(0.18)\end{array}$ & $\begin{array}{l}0.065 \\
(0.23)\end{array}$ & $\begin{array}{c}0.08 \\
(0.36)\end{array}$ & $\begin{array}{c}0.03 \\
(0.42)\end{array}$ & $\begin{array}{c}0.13 \\
(0.91)\end{array}$ & $\begin{array}{c}0.22 \\
(0.17)\end{array}$ & $\begin{array}{l}-0.15 \\
(0.53)\end{array}$ & $\begin{array}{c}0.40 \\
(0.42)\end{array}$ & $\begin{array}{c}-0.00 \\
(0.00)\end{array}$ & $\begin{array}{c}-0.00 \\
(0.00)\end{array}$ & $\begin{array}{l}-0.00 \\
(0.97)\end{array}$ & $\begin{array}{c}0.56^{* *} \\
(0.05)\end{array}$ & $\begin{array}{l}0.40^{*} \\
(0.18)\end{array}$ & $\begin{array}{c}0.42^{* *} \\
(0.03)\end{array}$ \\
\hline
\end{tabular}

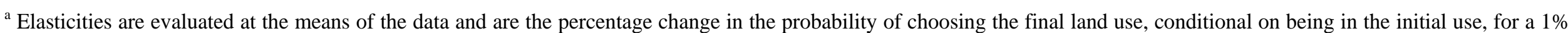

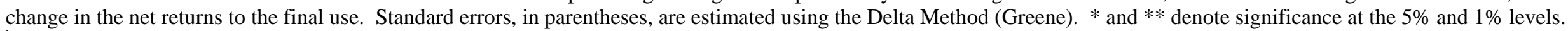

b There are no own-return elasticities for choosing CRP as net returns for CRP are not explicitly included in the econometric model. 
Table 4. Description of Simulation Scenarios

Scenario

Description

Factual

All returns at actual historical values.

No Change in Crop Market Returns

Fix crop returns from market (but not government payments) at 1978 values.

No Change in Government Payments

Fix government farm payments at 1978 values

No Government Payments

Set government farm payments at zero.

No Conservation Reserve Program (CRP) Eliminate CRP as land-use option.

No Government Payments and no CRP Set government farm payments at zero and remove CRP as land-use option.

No Change in Pasture Returns

Fix pasture returns at 1978 values.

No Change in Forest Returns

Fix forest returns at 1978 values.

No Change in Urban Returns

Fix urban returns at 1978 values.

No Change in Range Returns

Fix range returns at 1978 values. 
Table 5. Simulated Change in Crop Acreage in Contiguous United States, 1982-97

\begin{tabular}{lccc}
\hline \hline \multicolumn{1}{c}{ Scenario } & $\begin{array}{c}\text { Change in Crop } \\
\text { Acres } \\
(1,000 \mathrm{~s})\end{array}$ & $\begin{array}{c}\text { Percentage } \\
\text { of Factually } \\
\text { Simulated } \\
\text { Change }\end{array}$ & $\begin{array}{c}\text { Maximum Percentage } \\
\text { of Acreage Change } \\
\text { Attributable } \\
\text { to Variable Fixed }\end{array}$ \\
\hline Factual Simulation & $-41,137$ & $100.0 \%$ & $0.0 \%$ \\
\hline No Change in Crop Market Returns & $-23,477$ & $57.1 \%$ & $-42.9 \%$ \\
\hline No Change in Govt. Payments & $-44,670$ & $108.6 \%$ & $8.6 \%$ \\
\hline No Government Payments & $-48,627$ & $118.2 \%$ & $18.2 \%$ \\
\hline No CRP & $-11,826$ & $28.7 \%$ & $-71.3 \%$ \\
\hline No Govt. Payments and no CRP & $-16,359$ & $39.8 \%$ & $-60.2 \%$ \\
\hline No Change in Pasture Returns & $-48,262$ & $117.3 \%$ & $17.3 \%$ \\
\hline No Change in Forest Returns & $-42,532$ & $103.4 \%$ & $3.4 \%$ \\
\hline No Change in Urban Returns & $-40,527$ & $98.5 \%$ & $-1.5 \%$ \\
\hline No Change in Range Returns & $-41,061$ & $99.8 \%$ & $-0.2 \%$ \\
\hline
\end{tabular}

${ }^{\mathrm{a}}$ The difference between the counterfactual and factual simulation divided by the factual simulation. Positive (negative) values indicate that the crop acreage decrease was smaller (greater) in the factual versus counterfactual simulation. When the historical changes are reduced by 5 (rather than 100) percent, the results in descending order are $0.00 \%,-2.25 \%, 0.42 \%, 0.89 \%,-3.70 \%,-3.16 \%, 0.87 \%, 0.02 \%,-0.10 \%$ and $-0.01 \%$. 
Table 6. Simulated Change in Conservation Reserve Program (CRP) Acreage in Contiguous United States, 1982-97

\begin{tabular}{lccc}
\hline \multicolumn{1}{c}{ Scenario } & $\begin{array}{c}\text { Change in CRP } \\
\text { Acres } \\
(1,000 \mathrm{~s})\end{array}$ & $\begin{array}{c}\text { Percentage } \\
\text { of Factually } \\
\text { Simulated } \\
\text { Change }\end{array}$ & $\begin{array}{c}\text { Maximum Percentage } \\
\text { of Acreage Change } \\
\text { Attributable } \\
\text { to Variable Fixed }\end{array}$ \\
\hline Factual Simulation & 32,437 & $100.0 \%$ & $0.0 \%$ \\
\hline No Change in Crop Market Returns & 26,368 & $81.3 \%$ & $-18.7 \%$ \\
\hline No Change in Govt. Payments & 34,048 & $105.0 \%$ & $5.0 \%$ \\
\hline No Government Payments & 35,718 & $110.1 \%$ & $10.1 \%$ \\
\hline No CRP & 0 & $0.0 \%$ & $-100.0 \%$ \\
\hline No Govt. Payments and no CRP & 0 & $0.0 \%$ & $-100.0 \%$ \\
\hline No Change in Pasture Returns & 31,540 & $97.2 \%$ & $-2.8 \%$ \\
\hline No Change in Forest Returns & 32,374 & $99.8 \%$ & $-0.2 \%$ \\
\hline No Change in Urban Returns & 32,475 & $100.1 \%$ & $0.1 \%$ \\
\hline No Change in Range Returns & 32,439 & $100.0 \%$ & $0.0 \%$ \\
\hline
\end{tabular}

${ }^{a}$ The difference between the counterfactual and factual simulation divided by the factual simulation. Positive (negative) values indicate that the CRP acreage increase was smaller (greater) in the factual versus counterfactual simulation. When the historical changes are reduced by 5 (rather than 100) percent, the results in descending order are $0.00 \%,-1.14 \%, 0.24 \%, 0.48 \%,-5.00 \%,-5.00 \%, 0.14 \%, 0.01 \%,-0.01 \%$ and $-0.00 \%$. 
Table 7. Simulated Change in Pasture Acreage in Contiguous United States, 1982-97

\begin{tabular}{llcc}
\hline \hline \multicolumn{1}{c}{ Scenario } & $\begin{array}{c}\text { Change in } \\
\text { Pasture Acres } \\
(1,000 \mathrm{~s})\end{array}$ & $\begin{array}{c}\text { Percentage } \\
\text { of Factually } \\
\text { Simulated } \\
\text { Change }\end{array}$ & $\begin{array}{c}\text { Maximum Percentage } \\
\text { of Acreage Change } \\
\text { Attributable } \\
\text { to Variable Fixed }\end{array}$ \\
\hline Factual Simulation & $-10,812$ & $100.0 \%$ & $0.0 \%$ \\
\hline No Change in Crop Market Returns & $-19,645$ & $181.7 \%$ & $81.7 \%$ \\
\hline No Change in Govt. Payments & $-9,257$ & $85.6 \%$ & $-14.4 \%$ \\
\hline No Government Payments & $-7,434$ & $68.8 \%$ & $-31.2 \%$ \\
\hline No CRP & $-8,205$ & $75.9 \%$ & $-24.1 \%$ \\
\hline No Govt. Payments and no CRP & $-4,546$ & $42.0 \%$ & $-58.0 \%$ \\
\hline No Change in Pasture Returns & $-2,826$ & $26.1 \%$ & $-73.9 \%$ \\
\hline No Change in Forest Returns & $-11,049$ & $102.2 \%$ & $2.2 \%$ \\
\hline No Change in Urban Returns & $-10,153$ & $93.9 \%$ & $-6.1 \%$ \\
\hline No Change in Range Returns & $-10,785$ & $99.7 \%$ & $-0.3 \%$ \\
\hline
\end{tabular}

${ }^{\mathrm{a}}$ The difference between the counterfactual and factual simulation divided by the factual simulation. Positive (negative) values indicate that the pasture acreage decrease was smaller (greater) in the factual versus counterfactual simulation. When the historical changes are reduced by 5 (rather than 100) percent, the results in descending order are $0.00 \%, 4.11 \%,-0.71 \%,-1.54 \%,-0.68 \%,-2.29 \%,-3.26 \%, 0.05 \%,-0.35 \%$ and $-0.01 \%$. 
Table 8. Simulated Change in Forest Acreage in Contiguous United States, 1982-97

\begin{tabular}{lccc}
\hline \hline \multicolumn{1}{c}{ Scenario } & $\begin{array}{c}\text { Change in Forest } \\
\text { Acres } \\
(1,000 \mathrm{~s})\end{array}$ & $\begin{array}{c}\text { Percentage } \\
\text { of Factually } \\
\text { Simulated } \\
\text { Change }\end{array}$ & $\begin{array}{c}\text { Maximum Percentage } \\
\text { of Acreage Change } \\
\text { Attributable } \\
\text { to Variable Fixed }\end{array}$ \\
\hline Factual Simulation & 1,847 & $100.0 \%$ & $0.0 \%$ \\
\hline No Change in Crop Market Returns & 293 & $15.9 \%$ & $-84.1 \%$ \\
\hline No Change in Govt. Payments & 2,033 & $110.0 \%$ & $10.0 \%$ \\
\hline No Government Payments & 2,259 & $122.3 \%$ & $22.3 \%$ \\
\hline No CRP & 2,122 & $114.8 \%$ & $14.8 \%$ \\
\hline No Govt. Payments and no CRP & 2,550 & $138.0 \%$ & $38.0 \%$ \\
\hline No Change in Pasture Returns & 2,958 & $160.1 \%$ & $60.1 \%$ \\
\hline No Change in Forest Returns & -616 & $-33.4 \%$ & $-133.4 \%$ \\
\hline No Change in Urban Returns & 3,181 & $172.2 \%$ & $72.2 \%$ \\
\hline No Change in Range Returns & 1,861 & $100.7 \%$ & $0.7 \%$ \\
\hline
\end{tabular}

${ }^{\mathrm{a}}$ The difference between the counterfactual and factual simulation divided by the factual simulation. Positive (negative) values indicate that the forest acreage increase was smaller (greater) in the factual versus counterfactual simulation. When the historical changes are reduced by 5 (rather than 100) percent, the results in descending order are $0.00 \%,-3.33 \%, 0.51 \%, 1.12 \%,-0.67 \%, 1.85 \%, 2.07 \%,-0.36 \%, 4.18 \%$ and $0.00 \%$. 
Table 9. Simulated Change in Range Acreage in Contiguous United States, 1982-97

\begin{tabular}{llcc}
\hline \hline \multicolumn{1}{c}{ Scenario } & $\begin{array}{c}\text { Change in Range } \\
\text { Acres } \\
(1,000 \mathrm{~s})\end{array}$ & $\begin{array}{c}\text { Percentage } \\
\text { of Factually } \\
\text { Simulated } \\
\text { Change }\end{array}$ & $\begin{array}{c}\text { Maximum Percentage } \\
\text { of Acreage Change } \\
\text { Attributable } \\
\text { to Variable Fixed }\end{array}$ \\
\hline Factual Simulation & $-7,971$ & $100.0 \%$ & $0.0 \%$ \\
\hline No Change in Crop Market Returns & $-8,601$ & $107.9 \%$ & $7.9 \%$ \\
\hline No Change in Govt. Payments & $-7,890$ & $99.0 \%$ & $-1.0 \%$ \\
\hline No Government Payments & $-7,771$ & $97.5 \%$ & $-2.5 \%$ \\
\hline No CRP & $-8,134$ & $102.1 \%$ & $2.1 \%$ \\
\hline No Govt. Payments and no CRP & $-7,950$ & $99.7 \%$ & $-0.3 \%$ \\
\hline No Change in Pasture Returns & $-9,067$ & $113.8 \%$ & $13.8 \%$ \\
\hline No Change in Forest Returns & $-3,998$ & $50.2 \%$ & $-49.8 \%$ \\
\hline No Change in Urban Returns & $-7,311$ & $91.7 \%$ & $-8.3 \%$ \\
\hline No Change in Range Returns & $-8,157$ & $102.3 \%$ & $2.3 \%$ \\
\hline
\end{tabular}

${ }^{\mathrm{a}}$ The difference between the counterfactual and factual simulation divided by the factual simulation. Positive (negative) values indicate that the range acreage decrease was smaller (greater) in the factual versus counterfactual simulation. When the historical changes are reduced by 5 (rather than 100) percent, the results in descending order are $0.00 \%,-1.30 \%,-0.05 \%,-0.13 \%, 0.05 \%,-0.08 \%,-0.15 \%,-0.11 \%,-0.67 \%$ and $0.08 \%$. 
Table 10. Simulated Change in Urban Acreage in Contiguous United States, 1982-97

\begin{tabular}{lccc}
\hline \hline \multicolumn{1}{c}{ Scenario } & $\begin{array}{c}\text { Change in Urban } \\
\text { Acres } \\
(1,000 \mathrm{~s})\end{array}$ & $\begin{array}{c}\text { Percentage } \\
\text { of Factually } \\
\text { Simulated } \\
\text { Change }\end{array}$ & $\begin{array}{c}\text { Maximum Percentage } \\
\text { of Acreage Change } \\
\text { Attributable } \\
\text { to Variable Fixed }\end{array}$ \\
\hline Factual Simulation & 25,635 & $100.0 \%$ & $0.0 \%$ \\
\hline No Change in Crop Market Returns & 25,062 & $97.8 \%$ & $-2.2 \%$ \\
\hline No Change in Govt. Payments & 25,736 & $100.4 \%$ & $0.4 \%$ \\
\hline No Government Payments & 25,855 & $100.9 \%$ & $0.9 \%$ \\
\hline No CRP & 26,043 & $101.6 \%$ & $1.6 \%$ \\
\hline No Govt. Payments and no CRP & 26,304 & $102.6 \%$ & $2.6 \%$ \\
\hline No Change in Pasture Returns & 25,657 & $100.1 \%$ & $0.1 \%$ \\
\hline No Change in Forest Returns & 25,821 & $100.7 \%$ & $0.7 \%$ \\
\hline No Change in Urban Returns & 22,336 & $87.1 \%$ & $-12.9 \%$ \\
\hline No Change in Range Returns & 25,704 & $100.3 \%$ & $0.3 \%$ \\
\hline
\end{tabular}

${ }^{\mathrm{a}}$ The difference between the counterfactual and factual simulation divided by the factual simulation. Positive (negative) values indicate that the urban acreage increase was smaller (greater) in the factual versus counterfactual simulation. When the historical changes are reduced by 5 (rather than 100) percent, the results in descending order are $0.00 \%,-0.11 \%, 0.02 \%, 0.04 \%, 0.08 \%, 0.13 \%, 0.01 \%, 0.04 \%,-0.83 \%$ and $0.01 \%$. 